\title{
EFFECT OF PASTURE OR MAIZE SILAGE FEEDING ON THE NUTRITIONAL VALUE OF BEEF*
}

\author{
Andrzej Łozicki ${ }^{1}$, Maria Dymnicka ${ }^{1}$, Ewa Arkuszewska ${ }^{1}$, \\ Henryk Pustkowiak ${ }^{2}$ \\ ${ }^{1}$ Department of Animal Feeding and Feed Management, Warsaw University of Life Sciences, \\ Ciszewskiego 8, 02-786 Warsaw, Poland \\ ${ }^{2}$ Department of Cattle Breeding, University of Agriculture, al. 29 Listopada 46, \\ 31-425 Kraków, Poland
}

\begin{abstract}
The objective of this study was to evaluate the nutritional value of beef from different production systems. The study was conducted with Hereford bulls on organic and conventional farms. On the organic farm, fattening was mainly based on roughages, including pasture forage in the summer season, when the end of fattening occurred. On the conventional farm the bulls were fed maize silage and concentrate. On both farms, the animals were aged 7-9 months at the beginning of fattening. The bulls were fattened to a final body weight of 550-600 kg. Samples of longissimus thoracis muscle were collected from half-carcasses of slaughtered bulls originating from each farm to analyse fat content, fatty acid profile, and content of selected minerals and vitamin E. Muscle samples were additionally analysed for the concentration of thiobarbituric acid-reactive substances 3 and 7 days after slaughter. Analyses showed a lower fat content in longissimus thoracis muscle of bulls from the pasture feeding system. The fatty acid profile was also characterized by a lower content of $C$ 14:0, and a higher content of polyunsaturated fatty acids (PUFA), including C18:3 n-3, conjugated linoleic acid, $C$ 20:5 $n-3$, and $C$ 22:5 n-3, as well as by a lower ratio of $n-6 / n-3$ PUFA. The total content of monounsaturated fatty acids was significantly higher in animals fed maize silage and feed concentrate. In turn, the muscle of pasture fed animals had higher levels of $\mathrm{Na}, \mathrm{Zn}$ and Fe as well as of vitamin $E$.
\end{abstract}

Key words: beef cattle, beef production system, beef quality, fatty acids, vitamin E, lipid oxidation, minerals

Today in Poland, young fattening cattle are most often fed intensively or semiintensively, with feed rations based on preserved roughage, including mainly maize silage. Large-scale fattening rarely involves the extensive feeding of young cattle with green forage as the basal feed. Under Polish conditions, the application of ex-

*The project funded by the internal grant of Warsaw University of Life Sciences, no. 504-07040017. 
tensive and semi-intensive fattening which ends with pasture feeding, despite poorer production efficiency, affords the possibility of producing meat with a high nutritive value. Such a fattening system may be a fine alternative for farms possessing large areas of permanent grasslands, and particularly for organic farms.

Investigations show that pasture feeding of cattle, compared to feeding based on preserved roughage and high quantities of feed concentrates, leads to increased concentration of unsaturated fatty acids in meat (French et al., 2000; Realini et al., 2004; De la Fuente, 2009). Other reported effects of pasture feeding include improvement in n-3 to $n-6$ fatty acid ratio (Enser et al., 1999; De la Fuente et al., 2009), increased conjugated linoleic acid (CLA) content in meat (Shantha et al., 1997; Nuernberg et al., 2005), as well as increased content of vitamin E and other antioxidants (Yang et al., 2002; Mercier et al., 2003; Realini et al., 2004; De la Fuente et al., 2009). These changes resulting from pasture feeding improve nutritional values of meat as well as exert a positive effect on its colour and stability of fatty acids, by preventing oxidation. Pasture feeding may additionally produce beneficial effects on the mineral content of meat (Williams et al., 1983). Taking into account the positive effect of green crops on the nutritional value of meat, they should be provided to animals in the period preceding slaughter (Duckett and Wagner, 1993; De la Fuente, 2009).

The aim of the study was to determine the nutritional value of beef from fattened bulls fed green forage under organic farm conditions as well as maize silage and concentrate on a conventional farm.

\section{Material and methods}

The study was conducted in the years 2008-2009 at two farms located in northeastern Poland: an organic certified farm and a conventional farm.

\section{Animals}

Eight Hereford bulls were fattened on each farm. Fattening was begun in the autumn after calves were weaned from cows. The animals were aged 7-9 months at the beginning of fattening. The mean initial body weight of the bulls was $239 \mathrm{~kg}$ on the organic farm and $227 \mathrm{~kg}$ on the conventional farm. On the conventional farm, the bulls were kept tethered during the fattening period. On the organic farm, the animals were kept in pens (4 bullocks each) during winter feeding, and grazed on pasture in the summer season. The bulls from the conventional farm were slaughtered at the age of 15-16 months, and those from the organic farm at the age of 18-19 months. The body weight of the fattened bulls averaged $571 \mathrm{~kg}$ on the conventional farm and $563 \mathrm{~kg}$ on the organic farm.

\section{Feeding}

On the conventional farm, the animals were fed ad libitum maize silage, which was supplemented with a small amount of hay and with farm-produced concentrate (group MS). The concentrate was composed of triticale meal $(32 \%)$, barley meal 
$(20 \%)$, oat meal $(20 \%)$, rapeseed meal (25\%), supplementary vitamin-mineral mix $(2 \%)$, and limestone $(1 \%)$. The mean quantity of concentrate administered to animals over the entire fattening period was $4 \mathrm{~kg} /$ animal. The energy and protein content of feeds, percentage composition of the concentrate and concentrate ration were formulated according to IZ-INRA feeding standards (2001).

On the organic farm, the bull calves weaned from their mothers were administered ad libitum wilted grass silage, a small quantity of hay and farm-produced concentrate. The concentrate was composed of crops grown on the farm, i.e. triticale $(40 \%)$, oat $(30 \%)$, barley meal $(9 \%)$, broad bean $(20 \%)$, and limestone $(1 \%)$. Throughout the period of winter feeding the animals received, on average, $2 \mathrm{~kg}$ of concentrate per animal. After the period of winter feeding, the bulls were fattened on extensively used pasture. During the fattening period, samples of green forage were collected three times to analyse its nutritive value (Table 1). Stocking density of the bulls at the grazing plot analysed was 0.51 animal/ha (group PAS). At the end of the pasture season, the animals were slaughtered. The chemical composition and nutritive value of feedstuffs applied in both fattening systems are presented in Table 1.

Table 1. The chemical composition and nutritive value of feeds

\begin{tabular}{l|rr|r|rrr}
\hline \multirow{2}{*}{\multicolumn{1}{c}{ Item }} & \multicolumn{3}{c|}{ Conventional farm } & \multicolumn{3}{c}{ Organic farm } \\
\cline { 2 - 7 } & $\begin{array}{l}\text { maize } \\
\text { silage }\end{array}$ & hay & $\begin{array}{c}\text { concen- } \\
\text { trate }\end{array}$ & \multicolumn{3}{c}{ green forage } \\
\cline { 5 - 8 } & & & & May & June & August \\
\hline Dry matter (DM) (g/kg of fresh matter) & 307.6 & 876.9 & 885.8 & 237.2 & 250.2 & 299.9 \\
Crude ash (g/kg DM) & 43.9 & 57.1 & 147.2 & 77.2 & 57.2 & 96.7 \\
Total protein (g/kg DM) & 89.1 & 138.1 & 197.0 & 131.1 & 111.5 & 108.0 \\
Crude fat (g/kg DM) & 32.2 & 17.8 & 36.8 & 25.3 & 20.8 & 23.0 \\
Crude fibre (g/kg DM) & 241.5 & 334.4 & 44.1 & 273.6 & 314.5 & 296.1 \\
UFV/kg DM & 0.78 & 0.55 & 1.06 & 0.84 & 0.72 & 0.70 \\
PDIN (g/kg DM) & 55.27 & 85.53 & 126.44 & 80.10 & 67.95 & 66.69 \\
PDIE (g/kg DM) & 68.27 & 79.83 & 111.76 & 84.32 & 75.94 & 76.69 \\
CFU/kg DM & 1.15 & 1.12 & & 1.05 & 1.20 & 1.13 \\
\hline
\end{tabular}

Explanation of abbreviations:

UFV - unit of energy for meat production,

PDIN - protein digested in the small intestine depending on rumen degraded protein,

PDIE - protein digested in the small intestine depending on rumen-fermented organic matter,

CFU - fill unit for cattle.

\section{Meat}

The bulls were slaughtered in commercial slaughterhouses. From half-carcasses of 8 slaughtered bulls originating from each farm, longissimus thoracis muscle samples were collected $24 \mathrm{~h}$ after slaughter for analyses. The collected samples were transported to the laboratory and divided into about $2 \mathrm{~cm}$ thick portions that were next packed in foil bags. The samples to be analysed for fat content, fatty acid profile, and content of selected minerals ( $\mathrm{Ca}, \mathrm{P}, \mathrm{Mg}, \mathrm{Na}, \mathrm{K}, \mathrm{Fe}, \mathrm{Zn}, \mathrm{Cu}$ ) and vita- 
min $\mathrm{E}$ were frozen at $-20^{\circ} \mathrm{C}$ until analysed. In turn, the samples to be analysed for concentration of thiobarbituric acid reactive substances value as an indicator of lipid peroxidation were stored under chilling conditions and subjected to respective assays 3 and 7 days after slaughter.

\section{Analytical methods}

The chemical composition of feedstuffs and fat content of meat were determined according to AOAC methods (AOAC, 2005).

For fatty acid profile analysis, lipids were extracted according to the method of Folch et al. (1957) and fatty acids were esterified following the standard AOAC method (2005). The fatty acid analysis was conducted using a TRACE GC ULTRA gas chromatograph (Thermo Electron Corporation) on a SUPELCOWAX ${ }^{\mathrm{TM}} 10$ Capillary GC Column $(30 \mathrm{~m} \times 0.25 \mathrm{~mm} \times 0.25 \mu \mathrm{m})$ under the following conditions of the separation process: carrier gas - helium at a flow rate of $1.5 \mathrm{ml} / \mathrm{min}$, injector temperature $-220^{\circ} \mathrm{C}$, column temperature $-190^{\circ} \mathrm{C}$ for $3 \mathrm{~min} ; 3^{\circ} \mathrm{C} / \mathrm{min}$ to $220^{\circ} \mathrm{C}$; $35 \mathrm{~min}$ at $220^{\circ} \mathrm{C}$; and detector temperature $-250^{\circ} \mathrm{C}$.

The content of mineral components was determined at the Analytical Centre of the Warsaw University of Life Sciences by inductively coupled plasma optimal emission spectrometry (ICP-OES), according to the testing procedure of PB 35 (4th edition, 19 June 2008). Before the assay, the samples were microwave-mineralized in an open system.

The quantitative determinations of $\alpha$-tocopherol were performed using HPLC conducted with electrochemical detection according to ESA Application note. One gram of tissue was homogenized and extracted with $5 \mathrm{ml}$ of a hexane:ethanol mixture (50:50) with the addition of $0.01 \%$ butylhydroxyanisole (BHA). The tocopherols were extracted by mixing in Vortex for $60 \mathrm{~min}$ in the dark at about $4^{\circ} \mathrm{C}$ in hermetic vessels. The contents were then centrifuged in the Eppendorf 4250 centrifuge for $10 \mathrm{~min}$ at $11,000 \mathrm{rpm}$ and at $4{ }^{\circ} \mathrm{C}$. Afterwards, the hexane phase was collected. The prepared sample $(1 \mathrm{ml})$ was evaporated under gaseous nitrogen atmosphere and the dry residue was dissolved in $200 \mu \mathrm{l}$ mobile phase and then placed in an auto-sampler's carousel at $4^{\circ} \mathrm{C}$.

Malondialdehyde, the most abundant product of all lipid peroxidation products, was measured using thiobarbituric acid (TBA) according to Uchiyama and Mihara (1978) technique. The absorbance was measured at the wavelength of $535 \mathrm{~nm}$ with a Tecan Infinite M200 analyser (Tecan Group Ltd. Switzerland). The results represent the concentration of thiobarbituric acid reactive substances (TBARS) in the samples. The meat tissue was homogenized in $1 \%$ potassium chloride and centrifuged at $2000 \times \mathrm{g}$ for $15 \mathrm{~min}$ at $4^{\circ} \mathrm{C}$. The supernatant was used for the analysis and the tissues were placed in the reaction solution ( $1 \%$ phosphoric acid, $2 \%$ butylated hydroxytoluene, $1 \%$ potassium chloride and $0.4 \%$ TBA). The solution was stored at $95^{\circ} \mathrm{C}$ for $60 \mathrm{~min}$ prior to the analysis.

\section{Statistical analysis}

The results obtained were analysed statistically using one-way analysis of variance with the least squares method. The analysis involved the effect of feeding on the 
specified parameters. Results were presented in tables as mean values of parameters, standard errors of the means and the statistical significance of the effect. All calculations were performed with Statgraphics 6.0 Plus software.

\section{Results}

Table 2 presents the fat content and fatty acid composition of the analysed longissimus thoracis muscle samples. The meat from pasture fed animals was characterized by a significantly lower content of fat $(\mathrm{P} \leq 0.01)$. The total content of saturated fatty acids (SFA) in intramuscular fat was similar in both feeding groups. The analysis of the contribution of individual fatty acids to the total SFA pool did not reveal any significant differences between the groups for two fatty acids with hypercholesterolemic effects, i.e. C12:0 and C16:0. In the group fed maize silage and concentrate, analyses demonstrated a significantly higher concentration of $\mathrm{C} 14: 0(\mathrm{P} \leq 0.05)$. A significantly higher total content of monounsaturated fatty acids (MUFA) was determined in the meat of bulls fed maize silage. In the case of individual fatty acids, statistically significant differences were noted for $\mathrm{C} 16: 1 n-7(\mathrm{P} \leq 0.01), \mathrm{C} 17: 1$ $(\mathrm{P} \leq 0.01), \mathrm{C} 18: 1 n-9(\mathrm{P} \leq 0.01)$ and $\mathrm{C} 20: 1 n-9(\mathrm{P} \leq 0.05)$ acids. The total content of polyunsaturated fatty acids (PUFA) appeared to be higher in the meat of animals feeding on pasture $(\mathrm{P} \leq 0.01)$. Also the content of $n$-3 PUFA was higher in animals fed green forage $(\mathrm{P} \leq 0.001)$. The total content of $n-6$ fatty acids was similar in both feeding groups. A significantly lower $n-6 / n-3$ ratio was demonstrated in the meat of animals from the pasture feeding group $(\mathrm{P} \leq 0.001)$. Their meat was characterized by higher concentrations of fatty acids considered desirable from the viewpoint of human nutrition and with health-promoting effects, i.e. $\mathrm{C} 18: 3 n-3(\mathrm{P} \leq 0.001)$, conjugated linoleic acids (CLA) $(\mathrm{P} \leq 0.001)$ as well as $\mathrm{C} 20: 5 n-3(\mathrm{P} \leq 0.001)$ and $\mathrm{C} 22: 5$ $n-3(\mathrm{P} \leq 0.001)$.

Longissimus thoracis muscle of the animals fed green forage was characterized by a higher content of $\alpha$-tocopherol as compared to the muscle of bulls administered maize silage and concentrate $(\mathrm{P} \leq 0.05)$ (Table 3$)$.

The quality of meat is determined by the rate of lipid oxidation processes therein. The analysis of lipid oxidation index (TBARS) conducted 3 and 7 days after slaughter did not demonstrate any significant differences between the groups compared (Table 4). However, its higher value was noted in the muscle of the animals fed maize silage and concentrate. In both feeding groups, an increase in TBARS value was recorded between the first and the second measurement.

The analysis of the content of mineral components demonstrated that levels of most of the assayed macroelements, i.e. $\mathrm{Ca}, \mathrm{P}, \mathrm{Mg}$, and $\mathrm{K}$, in longissimus thoracis muscle were similar in both feeding groups (Table 5). Statistically significant differences were found for $\mathrm{Na}(\mathrm{P} \leq 0.01)$, the content of which was higher in the meat of bulls grazing on pasture. In the case of the analysed microelements, no statistically significant differences were observed in $\mathrm{Cu}$ content, whereas concentrations of $\mathrm{Fe}$ $(\mathrm{P} \leq 0.01)$ and $\mathrm{Zn}(\mathrm{P} \leq 0.001)$ were higher in the meat of bulls from the pasture feeding group. 
Table 2. Fatty acid profile and n-6/n-3 fatty acids ratio in raw longissimus thoracis muscle

\begin{tabular}{|c|c|c|c|c|}
\hline Item & MS* & PAS* & SE & $P$ \\
\hline \multirow[t]{2}{*}{ Crude fat $(\%)$} & 2.783 & 2.060 & 0.160 & 0.006 \\
\hline & \multicolumn{2}{|c|}{$\%$ of total fatty acids } & & \\
\hline SFA & 46.485 & 46.864 & 0.081 & 0.744 \\
\hline C10:0 & 0.048 & 0.046 & 0.027 & 0.609 \\
\hline C12:0 & 0.076 & 0.070 & 0.003 & 0.303 \\
\hline C14:0 & 2.023 & 1.770 & 0.073 & 0.032 \\
\hline $\mathrm{C} 15: 0$ & 0.411 & 0.372 & 0.018 & 0.150 \\
\hline C16:0 & 24.639 & 23.682 & 0.405 & 0.115 \\
\hline $\mathrm{C} 17: 0$ & 0.955 & 0.865 & 0.040 & 0.136 \\
\hline C18:0 & 18.049 & 19.760 & 0.699 & 0.103 \\
\hline C20:0 & 0.121 & 0.120 & 0.007 & 0.874 \\
\hline $\mathrm{C} 24: 0$ & 0.039 & 0.042 & 0.004 & 0.686 \\
\hline MUFA & 41.752 & 37.947 & 0.628 & 0.006 \\
\hline $\mathrm{C} 14: 1$ & 0.411 & 0.377 & 0.384 & 0.150 \\
\hline C16:1 n-9 & 0.314 & 0.283 & 0.012 & 0.097 \\
\hline C16:1 n-7 & 3.021 & 2.542 & 0.093 & 0.002 \\
\hline $\mathrm{C} 17: 1$ & 0.691 & 0.533 & 0.033 & 0.003 \\
\hline C18:1 n-9 & 32.954 & 29.803 & 0.623 & 0.002 \\
\hline $\mathrm{C} 18: 1 n-12$ & 0.705 & 0.792 & 0.037 & 0.121 \\
\hline C20:1 n-9 & 0.113 & 0.094 & 0.005 & 0.0154 \\
\hline $\mathrm{C} 24: 1 n-9$ & 0.057 & 0.047 & 0.005 & 0.195 \\
\hline PUFA & 9.669 & 12.560 & 0.593 & 0.003 \\
\hline C18:2 n-6 & 5.086 & 5.581 & 0.482 & 0.477 \\
\hline C18:3 n-6 & 0.164 & 0.149 & 0.009 & 0.304 \\
\hline $\mathrm{C} 18: 3 n-3$ & 0.707 & 1.290 & 0.028 & 0.000 \\
\hline CLA & 0.470 & 0.699 & 0.032 & 0.001 \\
\hline $\mathrm{C} 20: 2 n-6$ & 0.081 & 0.100 & 0.007 & 0.109 \\
\hline $\mathrm{C} 20: 3 n-6$ & 0.498 & 0.591 & 0.065 & 0.324 \\
\hline $\mathrm{C} 20: 4 n-6$ & 1.230 & 1.660 & 0.095 & 0.005 \\
\hline C20:5 n-3 & 0.409 & 0.776 & 0.0259 & 0.000 \\
\hline $\mathrm{C} 22: 4 n-6$ & 0.485 & 0.700 & 0.030 & 0.0001 \\
\hline $\mathrm{C} 22: 5 n-3$ & 0.441 & 0.918 & 0.038 & 0.000 \\
\hline $\mathrm{C} 22: 6 n-3$ & 0.095 & 0.091 & 0.009 & 0.801 \\
\hline$\sum n-3$ & 1.653 & 3.077 & 0.050 & 0.000 \\
\hline$\sum n-6$ & 7.545 & 8.784 & 0.609 & 0.170 \\
\hline$n-6 / n 3$ & 4.615 & 2.868 & 0.315 & 0.001 \\
\hline
\end{tabular}

* MS - feeding with maize silage and concentrate; PAS - pasture feeding.

Explanation of abbreviations:

SFA - calculated sum of fatty acids presented in the study that contain no double bonds,

MUFA - calculated sum of fatty acids presented in the study that contain 1 double bond,

PUFA - calculated sum of fatty acids presented in the study that contain 2 or more double bonds,

CLA - conjugated linoleic acid,

$\Sigma n-6$ - calculated sum of all n-6 fatty acids presented in the study,

$\sum n-3$ - calculated sum of all n-3 fatty acids presented in the study,

$n-6 / n 3$ - calculated ratio of n-6 to n-3 fatty acids. 
Table 3. Content of $\alpha$-tocopherol in raw longissimus thoracis muscle

\begin{tabular}{c|c|c|c|c}
\hline Item & MS* & PAS* & SE & P \\
\hline \multicolumn{7}{c}{$\mu \mathrm{g} / \mathrm{g}$ of fresh tissue mass } \\
$\alpha$-tocopherol & 3.88 & 4.61 & 0.019 & 0.018 \\
\hline
\end{tabular}

* MS - feeding with maize silage and concentrate; PAS - pasture feeding.

Table 4. Level of TBARS in longissimus thoracis muscle analysed 3 and 7 days after slaughter

\begin{tabular}{|c|c|c|c|c|}
\hline Item & $\mathrm{MS} *$ & PAS* & SE & $\mathrm{P}$ \\
\hline \multicolumn{5}{|c|}{ TBARS nmol/g of fresh tissue mass } \\
\hline 3 days & 0.464 & 0.417 & 0.0276 & 0.221 \\
\hline 7 days & 0.556 & 0.498 & 0.0289 & 0.178 \\
\hline
\end{tabular}

* MS - feeding with maize silage and concentrate; PAS - pasture feeding.

Table 5. Content of selected minerals in raw longissimus thoracis muscle

\begin{tabular}{|c|c|c|c|c|}
\hline Item & MS * & PAS* & SE & $\mathrm{P}$ \\
\hline \multicolumn{5}{|c|}{$\mathrm{mg} / \mathrm{kg}$ of fresh tissue mass } \\
\hline $\mathrm{Ca}$ & 61.3 & 63.5 & 1.608 & 0.351 \\
\hline $\mathrm{P}$ & 3027.1 & 2863.8 & 0.012 & 0.379 \\
\hline $\mathrm{Mg}$ & 408.9 & 372.0 & 15.609 & 0.114 \\
\hline $\mathrm{Na}$ & 510.9 & 586.6 & 18.404 & 0.010 \\
\hline K & 3913.5 & 3742.7 & 0.008 & 0.088 \\
\hline $\mathrm{Fe}$ & 29.7 & 37.1 & 1.200 & 0.005 \\
\hline $\mathrm{Zn}$ & 45.6 & 54.9 & 1.836 & 0.001 \\
\hline $\mathrm{Cu}$ & 1.2 & 1.1 & 0.039 & 0.336 \\
\hline
\end{tabular}

* MS - feeding with maize silage and concentrate; PAS - pasture feeding.

\section{Discussion}

The type of feeding in the fattening period was found to influence fat content of meat. Feeding green forage resulted in a lower deposition of intramuscular fat. This could be due to a lower energy value of green forage for most of the pasture period as compared to maize silage and concentrate (Table 1). Even longer fattening of animals and their slaughter at older age, which in the earlier maturing breeds may facilitate fat deposition, did not increase fat content of meat as compared to the animals administered maize silage and concentrate.

There were no differences in the total SFA concentrations between the treatment groups. The similar level of SFA in meat of both feeding groups analysed in this study corresponds with results of other researchers who investigated the effect of different feedstuffs applied in the fattening process on the content of fatty acids in meat and observed no differences (Dymnicka et al., 2006, De la Fuente et al., 2009). In contrast, in both our study and those of other authors, the feed ration was observed 
to influence concentrations of individual SFA. In the reported study, the meat of animals fed maize silage and concentrate was characterized by a significantly higher content of myristic acid (C14:0), which exhibits a strong hypercholesterolemic effect (Khosla and Sundram, 1996). In contrast, no differences were observed between the groups in the concentration of palmitic acid (C16:0), which is also implicated in increasing cholesterol level, especially in animals of advanced age. In another study investigating the impact of feeding on fatty acid composition in meat of Hereford steers, Realini et al. (2004) also demonstrated a higher concentration of C14:0 acid, but also of $\mathrm{C} 16: 0$ acid when the animals were administered feed rations based on maize silage and concentrate as compared to those grazing on pasture. Also De la Fuente et al. (2009), who analysed fatty acid composition in meat of animals from different feeding systems, reported not only a lower content of C14:0, but also of C16:0 for animals fed extensively with green forage. In turn, French et al. (2000), when comparing different feeding intensities based on grass silage, hay, green forage and concentrate, did not observe any statistically significant differences in concentrations of most medium-chain fatty acids, except for $\mathrm{C} 16: 0$, the content of which was the lowest in animals fed green forage only. The results of current study and those of other authors indicate that it is difficult to modify the content and composition of SFA in meat by the type of diet. Their content is related to a greater extent with the total content of intramuscular fat.

The results obtained in the present study indicate an increased content of MUFA in intramuscular fat for the diets based on maize silage. This concerns both the total content of MUFA and the concentrations of individual fatty acids, including C16:1 n-7, C17:1, C18:1 n-9, and C20:1 n-9. Among multiple effects, MUFA exert an antiatherogenic action. Of these acids, the strongest hypocholesterolemic effect is ascribed to oleic acid C18:1 (Spady et al., 1993). The beneficial effect of dietary maize silage on MUFA content of intramuscular fat was also demonstrated in earlier investigations, e.g. by Realini et al. (2004) on concentrations of C14:1, C16:1, C17:1, and C18:1 acids, and by Nuernberg et al. (2005) on the concentration of C16:1 acid. In turn, De la Fuente et al. (2009) who compared extensive feeding based only on pasture with the semi-intensive feeding system in which pasture feeding was followed by fattening in the intensive system, demonstrated a similar content of MUFA in meat of animals slaughtered at the age of two years, and an increasing content of these acids in animals fed extensively and slaughtered at the age of 3 years. The analysis of our own results and those of other authors suggests that intensive feeding of fattened bulls with maize silage and concentrate contributes to an increase in MUFA content of the meat. In contrast, pasture feeding does not increase the content of these acids in meat. As in the case of SFA, MUFA content increases more rapidly than PUFA content with carcass fatness, which is more conducive to intensive feeding with large amounts of concentrate.

Pasture feeding contributes to higher concentrations of PUFA in meat, including those of $n-3$ PUFA, which are of special interest in the human diet. It additionally results in a reduced ratio of $n-6 / n-3$ fatty acids. The results obtained in our study correspond with the findings of French et al. (2000) who observed that this ratio decreased with the increasing contribution of green forage to the feed ration and had 
the lowest value in animals fed exclusively green forage. In a study by Realini et al. (2004) with Hereford steers, feeding based on both maize silage and green forage resulted in a lower ratio of $n-6$ to $n-3$ fatty acids, as compared to the present study, i.e. 3.0 and 1.44, respectively. Also De la Fuente et al. (2009) demonstrated a lower $n-6 / n-3$ ratio in the animals fed extensively with green forage. In this fattening system, in animals slaughtered at the age of both 2 and 3 years, the ratio was similar and reached 1.37 and 1.48 , respectively.

In our study, the pasture feeding was observed to result in a significantly higher content of C18:3n-3, CLA and C20:5 n-3, and C22:5n-3, considered beneficial from the standpoint of human nutrition and exhibiting health-promoting effects. C18:3 n3 found in grass was deposited at a higher concentration in the meat of grass-fed animals. The increase in the proportion of C20:5n-3 and C22:5n-3 in the grass-fed animals suggests that the high availability of $\mathrm{C} 18: 3 n-3$ in grass resulted in enhanced synthesis of these long chain fatty acids. The C18:3 n-3 acid is a precursor of docosapentaenoic acid (C20:5 n-3) which, in addition to docosahexaenoic acid, is implicated to exert the greatest cholesterol-reducing effect. No differences were found in the content of docosahexaenoic acid in intramuscular fat between the animals fed on pasture and those receiving maize silage. The results obtained confirm previous findings which also demonstrate that pasture feeding enabled achieving higher concentrations of these acids (French et al., 2000; Realini et al., 2004; Nuernberg et al., 2005; De la Fuente, 2009). In a research by De la Fuente (2009), meat of animals fed extensively was characterized by over 3 times higher concentration of C18:3 $n-3$ acid as well as by over 2 times higher concentrations of C20:5n-3 and C22:5 $n-3$ acids compared to their concentrations reported in the meat of animals from the intensive fattening system. The higher proportion of CLA in the longissimus thoracis muscle of animals fattened at pasture indicates enhanced proportion of CLA in grass feeding compared with maize silage and concentrate feeding. Similar results were demonstrated by Realini et al. (2004) and French et al. (2000). CLA is implicated in the inhibition of carcinogenesis, the reduction of atherosclerosis, modification of the immune response, the distribution of body fat and a reduction in body fat deposits (Williams, 2000).

The analysis of $\alpha$-tocopherol performed in our study demonstrated its higher content in the meat of animals fed green forage compared to those administered maize silage and concentrate. This is consistent with the results reported by other authors who showed a lower content of vitamin E when comparing feeding based on preserved roughage to feeding based on green forage (Yang et al., 2002; Mercier et al., 2003; Realini et al., 2004; De la Fuente et al., 2009). The results obtained should be explained by a higher content of vitamin $\mathrm{E}$ in green parts of plants compared to the preserved feedstuffs, as well as by their better availability. Realini et al. (2004) noted a similar content of $\alpha$-tocopherol in meat of animals fed pasture forage and those fed intensively with the addition of 1000 IU of $\alpha$-tocopherol.

The higher concentration of vitamin $\mathrm{E}$ increases not only the nutritional values of meat but also enhances its oxygen stability (Roeber et al., 2001; Lauzurica et al., 2005). It is all the more significant that meat of animals fed green forage is additionally characterized by higher concentrations of PUFA, which are susceptible to 
oxidation. In that case, the higher content of vitamin E serves the protective function. By suppressing the oxidation of fatty acids of meat, vitamin $\mathrm{E}$ has an effect on improving such meat parameters as colour, aroma or texture (Arnold et al., 1993). In turn, Arnold et al. (1993) point to the positive effects of vitamin E in meat at levels reaching $3.5 \mu \mathrm{g} / \mathrm{g}$ fresh tissue. In the case of meat analysed in our study, in both feeding groups the content of vitamin E exceeded that level. These results indicate that feeding the animals good quality green forage allows obtaining a high content of vitamin $\mathrm{E}$ in meat without its addition to the diet. The higher content of vitamin $\mathrm{E}$ and PUFA in beef from pasture feeding indicated the positive effect of this system of feeding on the nutritional value of beef.

The content of such components of meat as vitamin E or PUFA affects the rate of oxidation processes in meat. The intensity of these processes is indicated by the level of malondialdehyde in meat which is the major product of lipid oxidation reacting with thiobarbituric acid (TBA). Johns et al. (1989) report that especially PUFA are susceptible to oxidation. A correlation between TBARS level and PUFA content in meat was also emphasized by Koger et al. (2010). In the reported study, despite a higher content of PUFA in meat of the animals from the PAS group, the level of TBARS was similar in both feeding groups. This pointed to the similar rate of oxidation processes. A lower TBARS value in meat of animals grazing on pasture, compared to those fed intensively based on concentrates, was demonstrated by Realini et al. (2004). In turn, Yang et al. (2002), who compared pasture feeding and intensive feeding with rations of concentrates supplemented or not supplemented with vitamin E, did not demonstrate the feeding system to affect the extent of lipid oxidation in fresh meat.

The factor limiting the course of lipid oxidation processes in the PAS group in our study could be a higher content of $\alpha$-tocopherol which increases the oxygen stability of meat. In contrast, the meat from the MS group was characterized by a higher content of fat, which diminishes the difference between groups in the total content of PUFA.

The nutritive value of meat is additionally affected by the content of minerals. The results of the present study indicate the effect of the feeding system on the mineral content of meat. In the case of pasture feeding, the meat was characterized by higher concentrations of $\mathrm{Na}, \mathrm{Fe}$ and $\mathrm{Zn}$. The levels of Fe and $\mathrm{Zn}$ determined in meat from both feeding groups were higher than the values reported by Willimson et al. (2005) for beef analysed in different countries. The content of these elements was also higher than the values presented by those authors for pork and lamb. The results reported by the authors cited above point to different content of minerals in different primal cuts, which has also been confirmed in other investigations (Gerber et al., 2009; Cabrera et al., 2010). The content of most minerals assayed in the studied meat $(\mathrm{Zn}, \mathrm{Fe}, \mathrm{Mg}, \mathrm{Ca})$ was higher when compared to the values reported by Florek et al. (2007) for bulls and heifers originating from the region of Lublin in Poland. This is especially evident for meat which in our study originated from animals reared on the pasture. In turn, Florek et al. (2007) reported a lower content of selected minerals in muscles of heifers, as compared to bulls, and demonstrated that the higher content of minerals in muscles might have been due to lower adiposity of the bull 
calves. Earlier, a higher mineral content of beef with a lower fat content were also reported by Williams et al. (1983). In our study, the higher content of some minerals was assayed in the meat of animals fed with green forage, which was additionally characterized by a lower fat content. This confirms the results reported by the authors quoted above.

In conclusion, the pasture feeding of bulls as compared to the feeding with preserved roughage (maize silage) and feed concentrate, enabled achieving a lower content of fat in their meat. In the case of pasture feeding, the fatty acid composition of longissimus thoracis muscle was characterized by a higher proportion of PUFA with hypocholesterolemic effects important from the viewpoint of human nutrition, i.e. C18:3n-3, C20:5n-3, and C22:5n-3, as well as of CLA exhibiting not only hypocholesterolemic action but also displaying beneficial effects on immunity, muscle weight increase and reduction of fatty tissue. The pasture feeding was also found to result in a more beneficial ratio of $n-6$ to $n-3$ PUFA, and in a lower concentration of undesirable C14:0 acid with the strongest hypercholesterolemic effect. It additionally increased the concentration of microlemements $(\mathrm{Zn}$ and $\mathrm{Fe})$ in meat, which is especially important in view of the fact that red meat is their major source. The intake of green forage by animals assured also a higher concentration of vitamin $\mathrm{E}$ in meat, which not only improves meat quality but is also an important antioxidant in human diet.

The results obtained in this study indicate that pasture feeding as compared to feeding preserved roughage and feed concentrate contributes to the production of meat of higher nutritional value.

\section{References}

AOAC (2005). Official Methods of Analysis of AOAC. International 16th Edition. Association of Analytical Chemists, Arlington, VA, USA.

Arnold R.N., Arp S.C., S cheller K.K., Willia m s S.N., S chaefer D.M. (1993). Tissue equilibration and subcellular-distribution of vitamin $\mathrm{E}$ relative to myoglobin and lipid oxidation in displayed beef. J. Anim. Sci., 71: 105-118.

Cabrera M.C., Ramos A., S a d oun A., Brito G. (2010). Selenium, copper, zinc, iron and manganese content of seven meat cuts from Hereford and Bradford steers fed pasture in Uruguay. Meat Sci., 84: 518-528.

De la Fuente J., Diaz M.T., Alvarez I., Oliver M.A., Font i Furnols M., Sanudo C., Campo M.M., Montos s F., Nute G. R., Caneque V. (2009). Fatty acid and vitamin $\mathrm{E}$ composition of intramuscular fat in cattle reared in different production systems. Meat Sci., 82: 331-337.

D u c k e t S.K., W a g n e r D.G. (1993). Effect of time on feed on beef nutrient composition. J. Anim. Sci., 71 (8): 2079-2088.

Dymnicka M., Łozicki A., Klupczyski J., Miciński J., Strzetelski J. (2006). Saturated and monounsaturated fatty acids in musculus thoracis of fattening bulls fed silage of grass and maize. Pol. J. Nat. Sci., 3: 185-191.

En s e r M., S c oll a n N.D., C h o i N.J., K u r t E., H a ll e t K., W o o d J.D. (1999). Effect of dietary lipid content on the conjugated linoleic acid (CLA) in beef muscle. Anim. Sci., 69: 143-146.

ESA - Application note. Simultaneous Analysis of Carotenoids, Retinoids, Tocopherols, Vitamin K1 and Coenzyme Q10 in Plasma. www.esainc.com

Florek M., Litwińczuk Z., Kędzierska-Matysek M., Grodzicki T., Skałecki P. 
(2007). Nutritional value of meat from musculus longissimus lumborum and musculus semitendinosus of young slaughter cattle (in Polish). Med.Wet., 63 (2): 242-246.

Folch J., L e es M., S l o a n e-S t a n le y G.H. (1957). A simple method for the isolation and purification of total lipids from animal tissues. J. Biol. Chem., 226: 497-509.

French P., Stanton C., Lawless F., O'Riordan E.G., Monahan F.J., Caffrey P.J., Moloney A.P. (2000). Fatty acid composition, including conjugated linoleic acid, of intramuscular fat from steers grazed grass, grass silage, or concentrate-based diets. J. Anim. Sci., 78: 2849-2855.

Gerber N., Brogioli R., Hat tendorf B., Schweeder M.R., Wenk C., Gunther D. (2009). Variability of selected trace element of different meat cuts determined by ICP-MS and DRC-ICOMS. Animal, 3: 166-172.

J ohn s A.M., B irkinshaw L.H., Le dward D.A. (1989). Catalysts of lipid oxidation in meat products. Meat Sci., 25: 209-220.

Khos la P., S undram K. (1996). Effect of dietary fatty acid composition on plasma cholesterol. Prog. Lipid Res., 35: 93-132.

Koger T.J., Wulf D.M., Weaver A.D., Wright C.L., Tjardes K.E., Mateo K.S., En g l e T.E., M a d d o c k R.J., S m a r t A.J. (2010). Influence of feeding various quantities of wet and dry distillers grains to finishing steers on carcass characteristics, meat quality, retail-case life of ground beef, and fatty acid profile of longissimus muscle. J. Anim. Sci., 88: 3399-3408.

Lauzurica S., De la Fuente J., Diaz M.T., Alvarez I., P erez C., Canegue V. (2005). Effect of dietary supplementation of vitamin $\mathrm{E}$ on characteristics of lamb meat packed under modified atmosphere. Meat Sci., 70: 639-646.

Mercier Y., Gatellier P., Renerre M. (2003). Lipid and protein oxidation in vitro, and antioxidant potential in meat from Charolais cows finished on pasture or mixed diet. Meat Sci., 66: $467-473$.

Nuernberg K., Dannenberger D., Nuernberg G., Ender K., Voigt J., S c olla n N.D., W o o d J.D., N u t e G.R., R i c hard s o n R.I. (2005). Effect of a grass-based and a concentrate feeding system on meat quality characteristics and fatty acid composition of longissimus muscle in different cattle breeds. Live. Prod. Sci., 94: 137-147.

Re alin i C.E., D u ckett S.K., Brito G.W., Dalla Rizza M., De Matos D. (2004). Effect of pasture vs. concentrate feeding with or without antioxidants on carcass characteristics, fatty acid composition, and quality of Uruguayan beef. Meat Sci., 66: 567-577.

R o e b e r D.L., B e lk K.E., T a t u m J.D., W i 1 s o n J.W., S m i th G.C. (2001). Effect of three levels of $\alpha$-tocopheryl acetate supplementation to feedlot cattle on performance of beef cuts during retail display. J. Anim. Sci., 79: 1814-1820.

S h a n th a N.C., M o o d y W.G., T a b e i d i Z. (1997). Conjugated linoleic acid concentration in semimembranous muscle of grass and grain-fed and zeranol-implanted beef cattle. J. Muscle Food, 8: $105-110$.

S pady D.K., W o o 11 e t t L.A., D i e t s chy J.M. (1993). Regulation of plasma LDL-cholesterol levels by dietary cholesterol and fatty acids. Ann. Rev. Nutr., 13: 355-381.

U c h i y a m a M., M i h a r a M. (1978). Determination of malonaldehyde precursor in tissue by thiobarbituric acic test. Anal. Biochem., 86: 271-278.

W i 1 i a m s C. (2000). Dietary fatty acids and human health. Ann. Zootech., 49: 165-180.

W i 11 i a m s J.E., W a g n e r D.G., W a $1 \mathrm{t}$ e r L.E., H orn G.W., W a 11 e r G.R., S i m s P.L., G u e n the r J.J. (1983). Effect of production systems on performance, body composition and lipid and mineral profiles of soft tissue in cattle. J. Anim. Sci., 57: 1020-1024.

Williams on C.S., Foster R.K., Stanner S.A., Buttris s J.L. (2005). Red meat in the diet. Br. Nutr. Fdn. Nutr. Bull., 30: 323-355.

Yang A., Lanari M.C., Brewster M., Tune R.K. (2002). Lipid stability and meat color of beef from pasture and grain-fed cattle with or without vitamin E supplementation. Meat Sci., 60: $41-50$. 
ANDRZEJ ŁOZICKI, MARIA DYMNICKA, EWA ARKUSZEWSKA, HENRYK PUSTKOWIAK

\author{
Wpływ żywienia pastwiskowego lub kiszonką z kukurydzy na wartość dietetyczną \\ mięsa wołowego
}

\title{
STRESZCZENIE
}

Celem pracy była ocena wartości dietetycznej mięsa wołowego uzyskanego przy różnych systemach produkcji. Badania przeprowadzono na buhajkach rasy Hereford $w$ gospodarstwach ekologicznym i konwencjonalnym. W gospodarstwie ekologicznym opas prowadzono głównie w oparciu o pasze objętościowe, w tym w okresie letnim, na który przypadał koniec opasu, o zielonkę pastwiskową. W gospodarstwie konwencjonalnym opasane buhajki otrzymywały w dawkach kiszonkę z kukurydzy oraz paszę treściwą. W obu gospodarstwach, na początku opasu zwierzęta były w wieku 7-9 miesięcy. Buhajki opasano do końcowej masy ciała mieszczącej się w przedziale $550-600 \mathrm{~kg}$. Z półtusz ubitych buhajków, z każdego gospodarstwa pobrano do analiz próbki mięśnia longissimus thoracis i oznaczono w nich zawartość tłuszczu, profil kwasów tłuszczowych, zawartość wybranych składników mineralnych oraz witaminę E. Oznaczono również poziom TBARS w 3. oraz 7. dniu po uboju.

Przy żywieniu pastwiskowym stwierdzono mniejszą zawartość thuszczu w badanym mięśniu. Mięsień $l$. thoracis zwierząt żywionych pastwiskowo charakteryzowała również mniejsza zawartość kwasu C14:0, wyższa PUFA, w tym C18:3 n-3, CLA, C20:5 n-3 i C22:5 n-3. Niższy był w nim również stosunek kwasów PUFA $n-6$ do $n-3$. Łączna zawartość kwasów MUFA była istotnie wyższa przy żywieniu kiszonką z kukurydzy i paszą treściwą. Przy żywieniu pastwiskowym stwierdzono wyższą zawartość $\mathrm{Na}, \mathrm{Zn}$ i Fe oraz witaminy E w badanym mięśniu. 